\title{
DOCKING MOLEKULER SENYAWA B-KAROTEN DALAM TANAMAN KELOR (MORINGA OLEIFERA,L) SEBAGAI PENGHAMBAT ENZIM TIROSINASE DENGAN AUTODOCK - VINA
}

\author{
Bayu Herdi Al Huda ${ }^{1}$, Nining Sugihartini ${ }^{2}$, Hari Susanti ${ }^{3}$, Dwi Utami ${ }^{4}$ \\ ${ }^{1}$ Mahasiswa Pascasarjana Farmasi Fakultas Farmasi Universitas Ahmad Dahlan \\ ${ }^{2}$ Laboratorium Kimia Analisis, Fakultas Farmasi Universitas Ahmad Dahlan \\ ${ }^{3}$ Laboratorium Teknologi Farmasi, Fakultas Farmasi Universitas Ahmad Dahlan \\ ${ }^{4}$ Laboratorium Kimia Organik, Fakultas Farmasi Universitas Ahmad Dahlan \\ *: bayucapatra@gmail.com
}

\begin{abstract}
ABSTRAK
Hidrokuinon telah digunakan dalam kosmetik karena memiliki aktivitas sebagai pemutih. Pada penelitian sebelumnya, $\beta$-Karoten dalam tanaman Kelor juga diketahui memiliki aktivitas sebagai penghambat enzim tirosinase. Perlu diketahui bagaimana mekanisme interaksi senyawa $\beta$-Karoten terhadap tirosinase (5M8N) dan senyawa manakah antara hidrokuinon dan $\beta$-karoten yang memberikan aktivitas sebagai pemutih yang lebih baik secara komputasi.Tirosinase dipreparasi menggunakan Discovery Studio Visualizer. Ligan dipreparasi dengan menggunakan Autodock 4.2. Autodock-Vina digunakan untuk docking antara protein dengan ligan. Tolok ukur yang menjadi hasil adalah nilai binding affinity (kkal/mol) ligan terhadap protein. Visualisasi docking antara ligan dan protein menggunakan Program Ligplot+ dengan lisensi 1 tahun. Media yang digunakan untuk proses docking adalah komputer berspesifikasi Intel Core i7-3770 CPU dengan kecepatan $3.40 \mathrm{GHz} 8$ cores, resolusi monitor 1920x1080p, VGA NVIDIA GeForce GTX 750, Memori RAM 8 gb, Windows 8 64-bit sebagai sistem operasi. Hasil docking didapatkan bahwa nilai binding affinity $\beta$ karoten terhadap tirosinase yaitu -11.2 sedangkan hidrokuinon dengan tirosinase yaitu -5.4 dengan RMSD 0. Hasil visualisasi didapatkan bahwa $\beta$-karoten lebih banyak mengikat asam amino reseptor daripada hidrokuinon. $\beta$-karoten dalam tanaman kelor terbukti secara aktif tidak hanya dalam uji in vitro di laboratorium basah, tapi juga aktif terapetik sebagai pemutih secara komputasi pada laboratorium kering.
\end{abstract}

Kata Kunci : Pemutih, $\beta$-karoten, kelor, docking Molekular, Autodock

\section{ABSTRACT}

Hydroquinone has been used in cosmetics because of its whitening activity. In previous studies, $\beta$-carotene in Moringa plants was also known as an inhibitor of the tyrosinase enzyme. It is necessary to know how the interaction mechanism of $\beta$-carotene with tyrosinase (5M8N) and which compounds between hydroquinone and $\beta$-carotene provide computationally better activity as whitening.

Tyrosinase was prepared using Discovery Studio Visualizer. Ligands were prepared using Autodock 4.2. Autodock-Vina is used for ligand docking between proteins. The result is the binding affinity ( $\mathrm{kcal} / \mathrm{mol})$ of the ligand to protein. Visualization of docking between ligands and proteins using the Ligplot + Program with a 1 year license. Media used for the docking process is a computer with an Intel Core i7-3770 CPU with a speed of $3.40 \mathrm{GHz} 8$ cores, 1920x1080p resolution, 
Jurnal Insan Farmasi Indonesia, 3(2) Desember 2020 (230-240)

Bayu Herdi Al Huda

p-ISSN 2621-3184; e-ISSN 2621-4032

doi: $10.36387 /$ jifi.v3i2.540

VGA NVIDIA GeForce GTX 750, 8 GB RAM, Windows 8 64-bit. The docking results showed that the binding affinity of $\beta$-carotene to tyrosinase was -11.2 while hydroquinone with tyrosinase was -5.4 with RMSD 0. The results of visualization showed that $\beta$-carotene binds more amino acid receptors than hydroquinone. $\beta$ carotene in moringa has been shown to be active not only in wet laboratories, but also in dry laboratories.

Keywords: Whitening, $\beta$-carotene, Moringa, Molecular docking, Autodock

\section{PENDAHULUAN}

Untuk menjadi bahan baku pemutih alami, maka dicari senyawa yang berperan aktif terhadap penghambatan enzim tirosinase. Tanaman kelor mengandung vitamin C, ß-karoten, asam tokoferol, flavonoid, fenolat, asam hidroksinamit, karotenoid, derivat, dan flavonoid ${ }^{1}$. Kandungan senyawa-senyawa antioksidan tersebut membuat daun kelor bisa dikembangkan sebagai bahan alam untuk pemutih. Bentuk daun kelor disajikan pada Gambar 1.

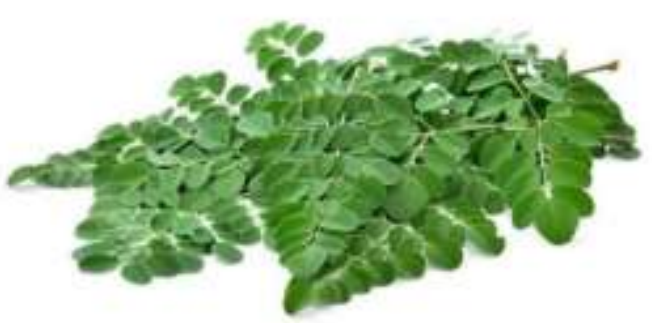

Gambar 1. Daun kelor (2).

Melanin merupakan pigmen warna kulit, yang diproduksi pada sel melanosit dan didistribusikan di antara keranosit pada lapisan dasar epidermis kulit. Pembentukan melanin akan lebih cepat apabila enzim tirosinase dalam keadaan aktif, akan tetapi keberadaan dan jumlah melanin pada kulit sangat mempengaruhi warna kulit ${ }^{4}$.

Sintesis melanin dimulai dengan adanya enzim tirosinase yang mengoksidasi asam amino L-Tirosin diubah membentuk L-DOPA oleh enzim tirosinase lalu enzim ini melalui reaksi oksidasi mengubah L-DOPA menjadi dopaquinon. Dopaquinon berubah langsung membentuk dopakrom dan produk akhirnya adalah melanin. Enzim tersebut dapat dihambat dengan penghambat tirosinase, di mana inhibitor ini dikatalis oleh tirosinase dan membentuk ikatan kovalen sehingga enzim menjadi tidak aktif selama reaksi katalitik berlangsung ${ }^{4}$.

Telah dilakukan penelitian tentang aktivitas tirosinase ekstrak etanol daun kelor (Moringa oleifera L.). Kelor mengandung senyawa flavonoid dan $\beta$ karoten golongan 
senyawa terpen yang merupakan senyawa yang dapat berpotensi untuk menghambat adanya tirosinase. Adanya inhibitor akan mengurangi dan menghentikan aktivitas tirosinase dalam memproduksi melanin yang nantinya akan mempengaruhi warna kulit.

Docking molekular merupakan metode penelitian yang dilakukan di laboratorium kering menggunakan perangkat komputer untuk menilai ikatan dan kemungkinan apakah senyawa tersebut bisa berikatan dan memberikan aktivitas sebelum diujikan. Docking molekul dilakukan untuk melihat senyawa aktif pemutih dalam daun kelor yaitu $\beta$-karoten yang mempunyai aktivitas memblok enzim tirosinase. Molecular docking dapat dilakukan dengan berbagai macam perangkat lunak gratis maupun berbayar. Penelitian in menggunakan perangkat lunak Autodock, untuk docking menggunakan program Vina, untuk preparasi ligan maupun reseptor menggunakan program Discovery Studio Visualizer dan untuk visualisasi hasil menggunakan program Ligplot+.

Program Autodock-Vina, Discovery Studio Visualizer dan
Ligplot+ dipilih karena tidak berbayar (gratis), mudah dioperasikan, akurat, memiliki tingkat error yang rendah dan hasilnya dapat dipercaya ${ }^{3}$. Metode Vina sendiri merupakan salah satu metode yang terdapat di program Autodock. Jika dibandingkan dengan program gratis lainnya, Vina memiliki keunggulan dalam melakukan docking yang cepat dan akurat. Proses docking dibutuhkan adanya senyawa pembanding dan senyawa yang kita uji terhadap reseptor yang ada di dalam tubuh.

Kontrol positif yang digunakan pada penelitian ini adalah hidrokuinon. Dengan adanya senyawa pembandingpembanding kita dapat melihat senyawa obat yang kita ujikan apakah benar - benar mempunyai aktivitas sebagai pemutih dalam kosmetik. Percobaan ini bertujuan untuk membandingkan senyawa yang digunakan sebagai pemutih dalam produk kosmetik di pasaran yaitu hidrokuinon dengan senyawa $\beta$ karoten yang ada dalam daun Kelor dan untuk mengetahui perbandingan interaksi ligan protein antara $\beta$-karoten dengan tirosinase dan hidrokuinon dengan tirosinase sebagai kontrol 
Jurnal Insan Farmasi Indonesia, 3(2) Desember 2020 (230-240)

Bayu Herdi Al Huda

p-ISSN 2621-3184 ; e-ISSN 2621-4032

doi: $10.36387 /$ jifi.v3i2.540

positif senyawa aktif pemutih pada kosmetik.

\section{METODE PENELITIAN}

\section{Alat dan Bahan}

Perangkat keras yang digunakan yaitu perangkat komputer lengkap dengan spesifikasi prosesor Intel Core i7-3770 CPU kecepatan 3.40 $\mathrm{GHz} 8$ cores, resolusi monitor 1920x1080p, RAM 16 GB, VGA NVIDIA GeForce GTX 750, Windows 8 64-bit. Perangkat lunak yang digunakan adalah AutoDock 4.2, Biovia Discovery Studio Visualizer, Ligplot 4.5.3, MGL Tools, Autodock Vina, Command Window.

\section{Subjek Penelitian}

Protein / Reseptor target yang digunakan yaitu tirosinase pada manusia. Reseptor / protein ini bisa didapatkan dari www.pdb.org dengan kata kunci PDB 5M8N : Crystal structure of human tyrosinase related protein 1 in complex with mimosine yang terdapat pada organisme homo sapiens dengan $X$-Ray difraction yang berada pada resolusi pengukuran adalah 2.60 Ả. Nilai R kerja 0.219, nilai $\mathrm{R}$ bebas 0.275 , dan nilai $\mathrm{R}$ pengamatan 0.222 dimana tidak terjadi mutasi.
Gambar reseptor 5M8N disajikan pada Gambar 2.

Ligan yang digunakan adalah $\beta$-karoten sebagai senyawa aktif pemutih dan antioksidan pada daun kelor dan hidrokuinon sebagai kontrol positif. Ligan $\beta$-karoten disajikan pada Gambar 4.

\section{Pengunduhan Protein dan Ligan}

Protein 5M8N diunduh dari www.pdb.org dan disimpan dalam bentuk .pdb. Ligan hidrokuinon dan ligan $\beta$-karoten diunduh dari dalam bentuk 3D dan disimpan dalam file type .sdf kemudian diubah file type nya menjadi .pdb dengan program Discovery Studio Visualizer lalu dilakukan preparasi pada Autodock $4.2^{5}$. Ligan hidrokuinon disajikan pada Gambar 5.

\section{Proses Preparasi Ligan dan Protein}

Sotware Discovery Studio Visualizer dipakai untuk menghapus ikatan protein dari ligan yang terikat di dalamnya dan membuang molekul air kemudian disimpan dalam ekstensi pdb. Berkas reseptor di preparasi dengan program Autodock 4.2 untuk menambah ikatan hidrogen kemudian di gabung lalu diikat dengan ligan untuk selanjutnya dipersiapkan untuk 
Jurnal Insan Farmasi Indonesia, 3(2) Desember 2020 (230-240)

Bayu Herdi Al Huda

p-ISSN 2621-3184 ; e-ISSN 2621-4032

doi: $10.36387 /$ jifi.v3i2.540

dimasukkan ke dalam grid box. Berkas reseptor tirosinase $5 \mathrm{M} 8 \mathrm{~N}$ disajikan pada Gambar 3.

Ligan $\beta$-karoten di preparasi dengan program Autodock 4.2 dengan menambah ikatan hidrogen serta mengubah ikatan aktif menjadi tidak berotasi. Berkas ligan kemudian disimpan dalam bentuk .pdbqt.

Protein dan ligan diubah menjadi berkas siap pakai berekstensi .pdb dengan program Discovery Studio

\section{Visualizer.}

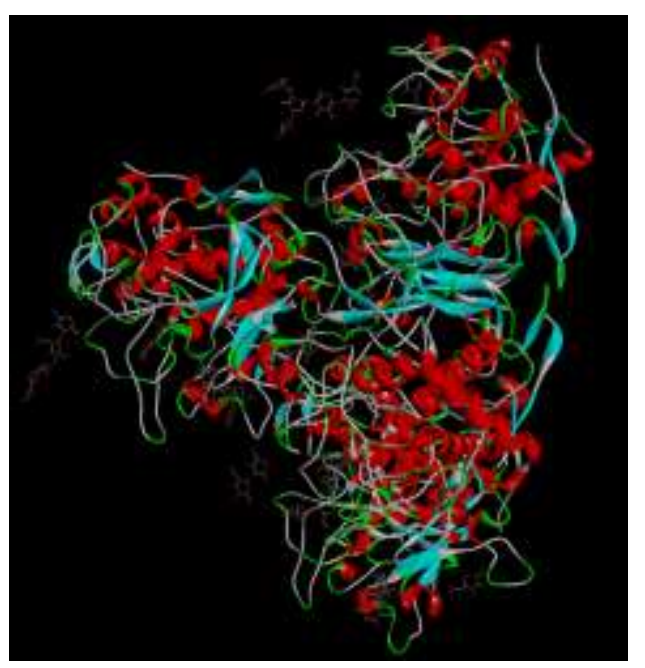

Gambar 2. Tirosinase (kode $5 \mathrm{M} 8 \mathrm{~N}$ ) hasil unduhan dari www.pdb.org sebelum di preparasi

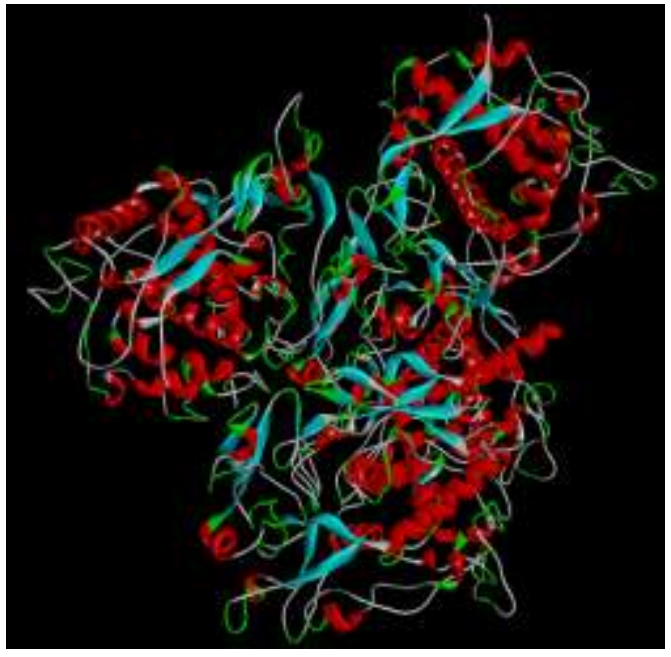

Gambar 3. Tirosinase (5) Setelah dipreparasi (dihilangkan molekul air dan ligan-ligannya).

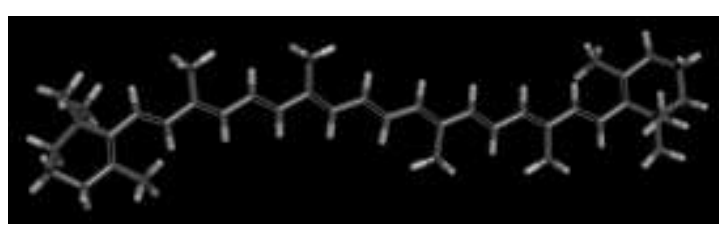

Gambar 4. Struktur 3D $\beta$-karoten (5).

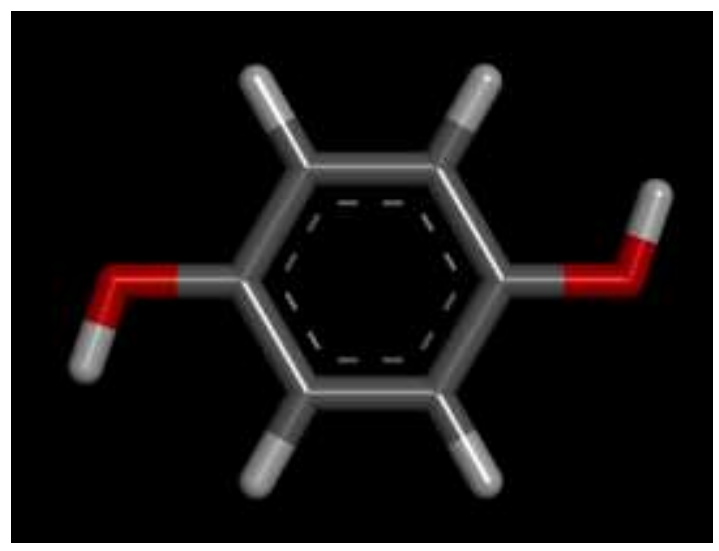

Gambar 5. Struktur 3D hidrokuinon (5).

\section{Validasi Metode Docking}

Tahapan selanjutnya adalah membuat grid box yang menutupi ikatan ligan dengan reseptor sebagai validasi docking. Bentuk grid box 
Jurnal Insan Farmasi Indonesia, 3(2) Desember 2020 (230-240)

Bayu Herdi Al Huda

p-ISSN 2621-3184 ; e-ISSN 2621-4032

doi: $10.36387 /$ jifi.v3i2.540

disajikan pada Gambar 7. Data hasil pembuatan grid box yang diperoleh berupa spacing dalam satuan angstrom, ukuran (x,y, dan $\mathrm{z})$ dan nilai center grid box (x,y, dan $\mathrm{z})$. Data kemudian disimpan dalam file config.txt untuk dasar ketika dijalankan docking menggunakan vina dan command window. Data hasil pembuatan grid box disajikan pada Gambar 6.

\begin{tabular}{|c|c|}
\hline \multicolumn{2}{|c|}{ Grid Options } \\
\hline Center & View Help \\
\hline $\begin{array}{l}\text { Current Total Grid Pts } \\
\text { number of points in } x\end{array}$ &  \\
\hline number of points in $y$ & $\begin{array}{l}\text { ension: } \\
\qquad\|\| \| 118 \text { ||||| }\end{array}$ \\
\hline number of points in $\mathrm{z}$ &  \\
\hline Spacing (angstrom): & IIII) 1.000 पाII \\
\hline Center Grid Box: & <offset> \\
\hline$x$ center: $\longdiv { - 1 5 . 6 6 8 }$ & पII 9.361 \\
\hline y center: 6.483 &  \\
\hline$z$ center: 1.885 & $\overline{\text { [III }}-8.528 \overline{\overline{11}}$ \\
\hline
\end{tabular}

Gambar 6. Data dalam grid box yang digunakan untuk memvalidasi proses docking

Penambatan protein pada ligan digunakan untuk mencari konformasi 3D ligan terhadap reseptor dengan melihat besaran grid box dan pusat massa dari tempat ikatan dalam satuan Angstrom. Nilai konformasi 3D dinyatakan dengan nilai RMSD. Nilai RMSD itu sendiri adalah kurang dari 5, semakin mendekati 0 akan lebih baik dan dapat diterima.

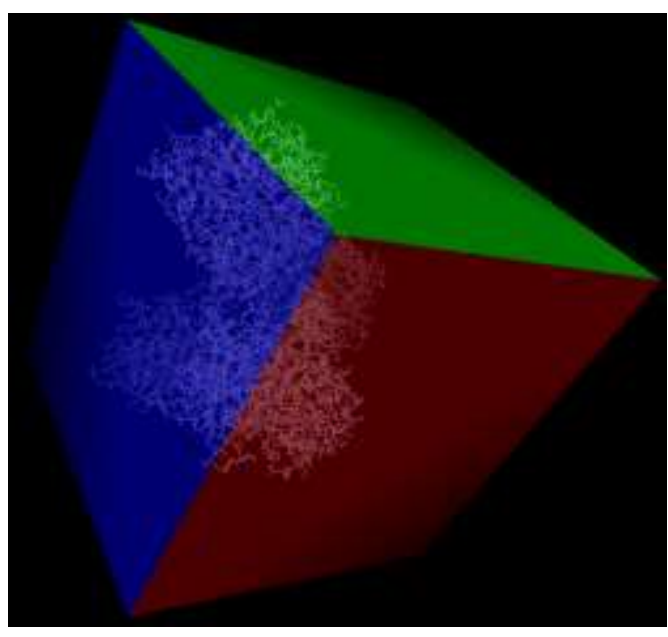

Gambar 7. Grid Box sebagai validasi ikatan ligan dengan protein.

\section{Docking Molekular dan Analisis Data}

Docking ligan dilakukan untuk menghasilkan nilai binding energi dalam satuan $\mathrm{kkal} / \mathrm{mol}$. Nilai binding energy yang semakin baik adalah nilai yang semakin kecil mendekati nilai minus 12. Jika nilai mendekati minus 12, maka kekuatan ikatan secara hitungan bisa terjadi. Data ligan $\beta$ karoten yang sudah dikumpulkan dibandingkan dengan data ligan hidrokuinon. Data interaksi protein dengan ligan disajikan dengan menggunakan Command Window hasil 
Jurnal Insan Farmasi Indonesia, 3(2) Desember 2020 (230-240)

Bayu Herdi Al Huda

p-ISSN 2621-3184 ; e-ISSN 2621-4032

doi: $10.36387 /$ jifi.v3i2.540

docking menggunakan vina atau dengan melihat berkas log.txt. Isi dari berkas log.txt disajikan pada Gambar 8.

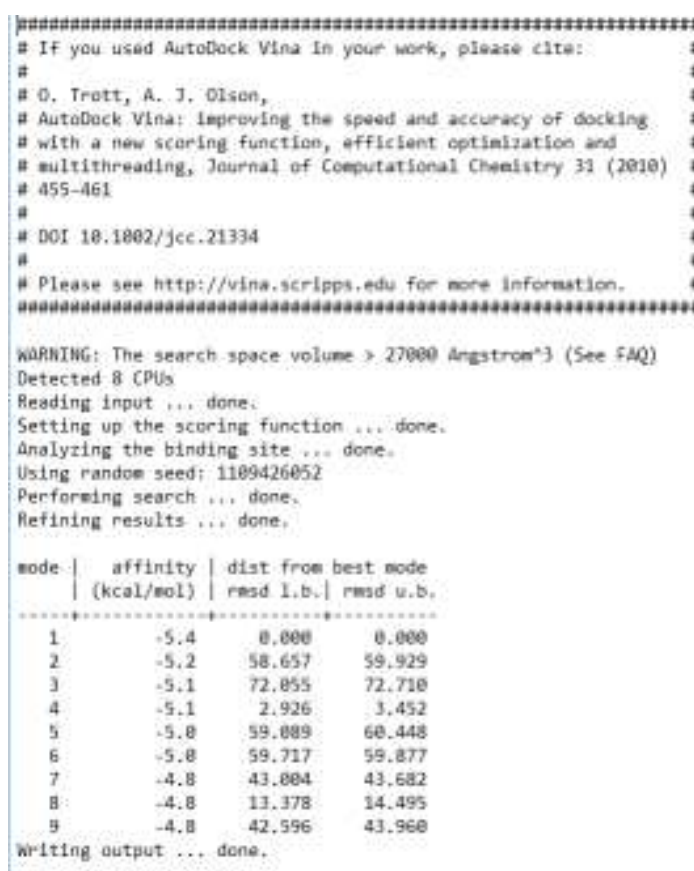

Gambar 8. Laporan proses docking ligan dengan protein menggunakan Vina dan Command Window

\section{HASIL DAN PEMBAHASAN}

Makromolekul protein target tirosinase menjadi target ikatan obat dengan reseptor. Ligan dan protein yang telah diunduh kemudian dipreparasi sehingga didapatkan protein tanpa ligan dan air dengan Perangkat lunak Discovery Studio. Berkas protein dipreparasi dengan program Autodock 4.2 untuk menambah ikatan hidrogen polar kemudian di merge lalu diikat dengan 
Jurnal Insan Farmasi Indonesia, 3(2) Desember 2020 (230-240)

Bayu Herdi Al Huda

p-ISSN 2621-3184 ; e-ISSN 2621-4032

doi: $10.36387 /$ jifi.v3i2.540

Tabel 2. Besaran nilai pusat massa dari ligan

\begin{tabular}{llll}
\hline Ligan & $\mathrm{X}$ & $\mathrm{Y}$ & $\mathrm{Z}$ \\
\hline B-Karoten & - & 4,934 & - \\
& 11,151 & & 2,818 \\
Hidrokuinon & - & 6,377 & 1,866 \\
& 15,377 & & \\
\hline
\end{tabular}

Hasil docking hidrokuinon dengan tirosinase dengan ligan di dalamnya disajikan pada Gambar 9. Hasil docking $\beta$-karoten dengan tirosinase dengan ligan di dalamnya disajikan pada Gambar 11. Dari proses docking didapat data bahwa $\beta$-karoten memiliki konformasi yang mirip dengan hidrokuinon yang menggunakan algoritma Vina. Sistem docking untuk pusat massa dan besaran volume gridbox sudah cocok dan valid. Kedekatan konformasi ligan 3D dinyatakan dengan nilai RMSD. Pengukuran dengan kristalografi diketahui bahwa RMSD bernilai di bawah 5. Pengujian sistem docking diperlukan sebagai pengujian aktivitas dan memprediksi hasil dan kemiripan interaksi antara $\beta$-karoten-tirosinase dengan hidrokuinon-tirosinase.

Penambatan antara ligan dengan reseptor diketahui kekuatannya dari bentuk ligan yang mempunyai energi terkecil. Binding affinity adalah

nilai yang menunjukkan kemampuan ligan berikatan dengan reseptor. Jika semakin besar nilai afinitas ikatan, maka afinitas antara reseptor dengan ligan akan semakin rendah. Semakin kecil nilai afinitas binding, maka afinitas antara reseptor dengan ligan semakin tinggi.

Nilai energi dari tirosinase dan $\beta$-karoten/hidrokuinon dengan program Autodock - Vina disajikan pada Tabel 3. Senyawa uji yang akan dibandingkan dengan ligan hidrokuinon. Hasil pada Tabel 3, nilai afinitas ikatan $\beta$-karoten tidak melebihi hidrokuinon. Sehingga afinitas ikatan antara reseptor tirosinase ke senyawa $\beta$-karoten cenderung rendah sehingga $\beta$-karoten lebih mudah mengikat tirosinase untuk menghambat aktivitasnya untuk memproduksi melanin.

Pada proses visualisasi hasil dengan menggunakan program Ligplot+, diketahui bahwa ligan $\beta$ karoten ternyata menghasilkan ikatan hidrofobik yang mirip dengan ligan hidrokuinon. Interaksi ligan protein $\beta$ karoten ditemukan sama dengan ikatan ligan protein hidrokuinon. Hasil visualisasi Ligplot+ juga menunjukkan 
Jurnal Insan Farmasi Indonesia, 3(2) Desember 2020 (230-240)

Bayu Herdi Al Huda

p-ISSN 2621-3184 ; e-ISSN 2621-4032

doi: $10.36387 /$ jifi.v3i2.540

jumlah asam amino yang lebih banyak

diikat oleh $\beta$-karoten daripada

hidrokuinon. Hal tersebut

menunjukkan semakin efektif $\beta$ -

karoten dalam berikatan dengan asam

amino dalam tirosinase di tubuh.

Senyawa $\beta$-karoten dalam tanaman

kelor terbukti secara aktif tidak hanya

dalam uji in vitro di laboratorium

basah, tapi juga aktif terapetik sebagai

pemutih secara komputasi pada

laboratorium kering. Hasil visualisasi

antara hidrokuinon dan tirosinase

disajikan pada Gambar 10, sedangkan

visualisasi antara $\beta$-karoten dengan

tirosinase disajikan pada Gambar 12.

Tabel 3. Nilai Binding Affinity antara tirosinase dengan $\beta$-karoten serta tirosinase dengan hidrokuinon

\begin{tabular}{ccccc}
\hline $\begin{array}{c}\text { Algori } \\
\text { tma }\end{array}$ & \multicolumn{2}{c}{$\begin{array}{c}\text { Binding } \\
\text { (kkal/mol) }\end{array}$} & & \\
\cline { 2 - 5 } & $\beta-$ & Hidrok & $\beta-$ & Hidrok \\
& $\begin{array}{c}\text { Karo } \\
\text { ten }\end{array}$ & uinon & Karo & uinon \\
Vina & - & $-5,4$ & 0 & 0 \\
& 11,2 & & & \\
\hline
\end{tabular}



Gambar 9. Hasil docking hidrokuinon dengan tirosinase dengan ligan di dalamnya.

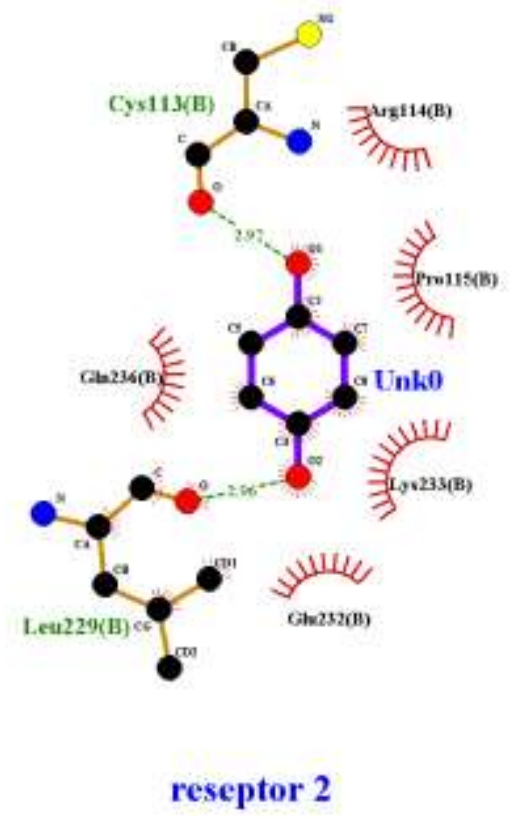

Gambar 10. Visualisasi docking hidrokuinon dengan tirosinase sebagai whitening menggunakan autodock 4.2 -Vina. 




Gambar 11. Hasil docking $\beta$-karoten dengan tirosinase dengan ligan di dalamnya.

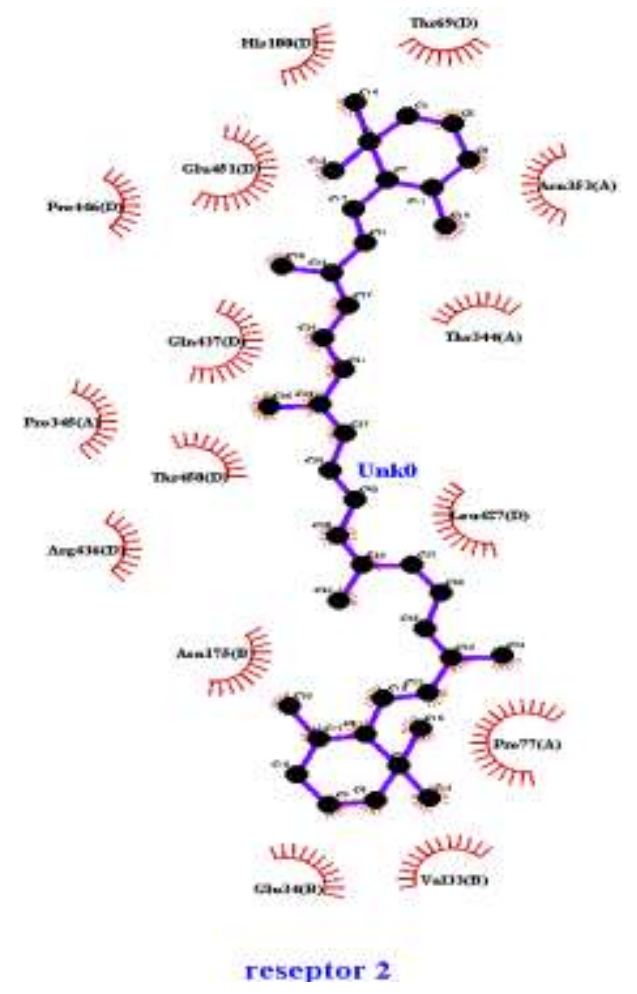

Gambar 12. Visualisasi docking $\beta$ karoten dengan tirosinase sebagai whitening menggunakan Autodock 4.2-Vina

\section{KESIMPULAN}

Berdasarkan uji coba docking di laboratorium kering, senyawa $\beta$ karoten mempunyai nilai afinitas ikatan lebih tinggi dibandingkan dengan hidrokuinon. Hal ini menunjukkan bahwa $\beta$-karoten lebih poten daripada hidrokuinon dalam menghambat aktivitas enzim tirosinase. B-karoten dalam tanaman kelor terbukti secara aktif tidak hanya dalam uji in vitro di laboratorium basah, tapi juga aktif terapetik sebagai pemutih secara komputasi pada laboratorium kering.

\section{UCAPAN TERIMA KASIH}

Ucapan terimakasih kami persembahkan kepada Universitas Ahmad Dahlan selaku fasilitator dalam penelitian ini.

\section{DAFTAR PUSTAKA}

1. Putra, I., Dharmayudha, A., \& Sudimartini, L. 2017. Identifikasi Senyawa Kimia Ekstrak Etanol Daun Kelor (Moringa oleifera. L) di Bali. Indonesia Medicus Veterinus, 5(5), 464-473.

2. Emantipati.com. Diakses pada tanggal 29 November 2020

3. Trott, O. \& Olson, A.J. 2010. AutoDock Vina: improving the speed and accuracy of docking with a new scoring function, efficient optimization and multithreading, Journal of Computational Chemistry, 31: 
Jurnal Insan Farmasi Indonesia, 3(2) Desember 2020 (230-240)

Bayu Herdi Al Huda

p-ISSN 2621-3184 ; e-ISSN 2621-4032

doi: 10.36387/jifi.v3i2.540

455-461.

4. Abidin, Z., Khaeriah, U., Zuhrina, Z., Pratama, M., \& Baits, M. 2019. Tyrosinase Inhibitor Activity Measurement of Crude and Purified Extract of Moringa Leaves (Moringa oleifera L.). Indonesian Journal of Pharmaceutical Science and Technology, 1(1).https://doi.org/10.24198/IJPS T.V1I1.19152.
5. Pubchem.ncbi.nlm.nih.gov.

Diakses pada 29 November 2020.

6. Luthfiyah Y. \& Santoso B. (2014)

Pemodelan Tiga Dimensi (3D) Ikatan Hasil Docking Molekular Turunan Diketopiperazin (DKP) Dengan Bcl-2 Pada Sel MCF-7. Skripsi. Fakultas Farmasi Universitas Muhammadiyah Surakarta 